Jurnal Independent Vol 4 No. 2

\title{
TINJAUAN YURIDIS MENGENAI PERCERAIAN PEGAWAI NEGERI SIPIL YANG TIDAK ADA IZIN PEJABAT ATASAN LANGSUNG
}

\author{
Oleh \\ Suisno \\ Dosen Fakultas Hukum Universitas Islam Lamongan
}

\begin{abstract}
ABSTRAK
Proses Perceraian bagi Pegawai Negeri Sipil pada dasarnya sama dengan Perceraian orang-orang yang bukan Pegawai Negeri Sipil. Perbedaanya, Pegawai Negeri Sipil baik laki-laki maupun perempuan yang bertindak sebagai penggugat atau pemohon, terlebih dahulu harus mendapat izin dari atasan dan pejabat. Sementara bagi Pegawai Negeri Sipil baik laki-laki muapun perempuan yang melakukan Perceraian dan berkedudukan sebagai tergugat wajib memberitahukan secara tertulis adanya gugatan dari suami atau istrinya kepada Pejabat untuk mendapat surat keterangan. Berdasarkan latar belakang masalah diatas, penulis mengetengahkan dua permasalahan yaitu Bagaimana Pengaturan Perceraian Bagi Pegawai Negeri Sipil ? Apakah akibat hukum Perceraian Pegawai Negeri Sipil tanpa seizin Pejabat atasan langsung ?. Tujuan Penulis untuk mengetahui prosedur Perceraian Bagi Pegawai Negeri Sipil dan untuk mengetahui akibat hukum Perceraian Pegawai Negeri yang tanpa seizin Pejabat atasan langsung. Manfaat Penulisan untuk memberikan pengetahuan tentang Pengaturan Perceraian Pegawai Negeri sipil dan Akibat hukum Perceraian Pegawai Negeri Sipil tanpa seizin Pejabat atasan langsung.Tipe penelitian hukum yang digunakan adalah yuridis normatif (hukum normatif ) Metode Penelitian hukum normatif adalah suatu prosedur penelitian ilmiah untuk menemukan kebenaran berdasarkan logika keilmuan hukum dari sisi normatifnya. Pendekatan yang digunakan adalah pendekatan perundang-undangan yang berhubungan dengan pokok permasalahan yang terkait dengan Perceraian Pegawai Negeri Sipil tanpa seizin pejabat. Bahan hukum dalam penulisan ini mengunakan bahan hukum primer dan bahan hukum sekunder . Dari pembahasan bab perbab dapat disimpulkan bahwa Pengaturan Perceraian Bagi Pegawai Negeri Sipil terdapat dalam Peraturan Pemerintah Nomor 45 Tahun 1990 Tentang Perubahan atas Perceraian Pemerintah Nonor 10 Tahun 1983 Tentang Perkawinan dan Perceraian Bagi Pegawai Negeri Sipil.
\end{abstract}

Kata Kunci : Tinjauan Yuridis,Perceraian Pegawai Negeri Sipil, pejabat atasan.

\section{PENDAHULUAN}

\section{A. Latar Belakang Masalah}

Pegawai Negeri Sipil

(PNS) merupakan unsur aparatur negara, abdi negara, dan abdi masyarakat dalam tingkah laku, tindakan, dan ketaatan kepada peraturan perundang-undangan, termasuk dalam menyelenggarakan kehidupan rumah tangga.Kehidupan Pegawai Negeri Sipil yang bersangkutan dapat melaksanakan tugasnya dengan 
baik tanpa harus terganggu oleh masalah keluarga.

\section{B. Perumusan Masalah}

Berdasarkan

latar

belakang masalah diatas, penulis merumuskan permasalahan sebagai berikut:

1. Bagaimana Pengaturan Perceraian Bagi Pegawai Negeri Sipil ?

2. Apakah Akibat Hukum Perceraian Pegawai Negeri Sipil Tanpa Seizin Pejabat Atasan Langsung?

\section{Tujuan Penelitian}

1. Untuk mengetahui bagaimana Pengaturan Perceraian Bagi Pegawai Negeri Sipil.

2. Untuk mengetahui apa Akibat Hukum Perceraian Pegawai Negeri Sipil Tanpa Seizin Pejabat Atasan Langsung.

\section{Manfaat Penelitian}

Dalam penulisan ini diharapkan bermanfaat bagi :

1. Manfaat teoritis yaitu, untuk memberikan pengetahuan tentang Pengaturan Perceraian Bagi Pegawai Negeri Sipil dan apakah Akibat Hukum Perceraian Pegawai Negeri Sipil Tanpa Seizin Pejabat Atasan Langsung.

2. Manfaat praktis yaitu, dapat memberikan kajian akibat dari perceraian tanpa seizin pejabat atasan langsung.

\section{E. METODE PENELITIAN}

\section{Tipe Penelitian}

Tipe penelitian yang dilakukan adalah Yuridis Normatif, Metode penelitian hukum normatif adalah suatu prosedur penelitian ilmiah untuk menemukan kebenaran berdasarkan logika keilmuan hukum dari sisi normatifnya.

2. Pendekatan Masalah

Oleh karena tipe penelitian yang digunakan adalah tipe penelitian yuridis normatif, maka pendekatan yang digunakan adalah pendekatan perundang-undangan (statue approach). Pendekatan terebut melakukan pengkajian peraturan perundang-undangan yang berhubungan dengan pokok permasalahan. Selain itu juga digunakan pendekatan konsep (conceptual approach).

3. Bahan Hukum
Bahan hukum yang dipergunakan dalam penelitian ini adalah sebagai berikut:

a. Bahan hukum primer, . Adapun hukum primer antara lain:

1) Undang-undang Nomor 1 Tahun 1974 Tentang Perkawinan

2) Undang-Undang

Nomor 5 Tahun 2014

Tentang Aparatur Sipil Negara

3) Peraturan Pemerintah Republik Indonesia Nomor 45 Tahun 1990 Tentang Perubahan Peraturan Pemerintah Republik Indonesia Nomor 10 Tahun 1983 Tentang Perkawinan dan Perceraian Pegawai Negeri Sipil

4) Peraturan Pemerintah Republik Indonesia 
TINJAUAN TENTANG

PERKAWINAN PEGAWAI NEGERI SIPIL

Perkawinan adalah perilaku mahluk ciptaan Tuhan Yang Maha Esa agar kehidupan di alam dunia berkembang biak. Aturan tata-tertib perkawinan sudah ada sejak masyarakat sederhana yang di pertahankan anggota-anggota masyarakat dan pera pemuka masyarakat adat dan atau para pemuka agama ,di Indonesia aturan tata-tertib perkawinan itu sudah ada sejak zaman kuno, sejak zaman Sriwijaya, Majapahit, sampai masa colonial Belanda dan sampai Indonesia merdeka.

\section{TINJAUAN TENTANG \\ PERCERAIAN PEGAWAI NEGERI SIPIL}

Sebagai unsur aparatur Negara, abdi Negara ,dan abdi masyarakat Pegawai Negeri Sipil dalam melaksanakan tugasnya diharapkan tidak terganggu oleh urusan kehidupan rumah tangga . Pegawai Negeri Sipil tertentu yang seharusnya terkena ketentuan Peraturan Pemerintah Nomor 10 Tahun 1983 dapat menghindar ,baik secara sengaja maupun tidak, terhadap ketentuan tersebut. Disamping itu ada kalanya pula pejabat tidak dapat megambil tindakan yang tegas karena ketidak jelasaan rumusan ketentuan Peraturan Pemerintah Nomor 10 Tahun 1983 itu sendiri

PENGATURAN HUKUM KHUSUS PERCERAIAN BAGI PEGAWAI NEGERI SIPIL
Pengaturan hukum khusus Perceraian bagi Pegawai Negeri Sipil terdapat dalam Peraturan Pemerintah Nomor 10 Tahun 1983 dan Peraturan Pemerintah Nomor 45 Tahun 1990 tentang Perubahan atas Peraturan Pemerintah Nomor 10 Tahun 1983 tentang Izin Perkawinan dan Perceraian bagi Pegawai Negeri Sipil, oleh karena itu pertimbangkan pengaturan hukum khusus bagi Pegawai Negeri Sipil dapat dipahami dari pertimbangan kedua Peraturan Pemerintah

\section{AKIBAT HUKUM PERCERAIAN PEGAWAI NEGERI SIPIL TANPA SEIZIN PEJABAT ATASAN LANGSUNG}

Menurut Pasal 3 Peraturan Pemerintah Nomor 45 Tahun 1990 tentang Perubahan atas peraturan Pemerintah Nomor 10 Tahun 1983 tentang Izin Perkawinan Dan Perceraian Bagi Pegawai Negeri Sipil. Pegawai Negeri Sipil yang akan melakukan Perceraian wajib memeperoleh izin atau surat keterangan lebih dahulu dari pejabat. Bagi Pegawai Negeri Sipil yang berkedudukan sebagai penggugat atau bagi Pegawai Negeri Sipil yang berkedudukan sebagai tergugat, untuk memperoleh izin atau surat keterangan tersebut, maka harus mengajukan permintaan secara tertulis, dalam surat permintaan izin atau pemberitauhan adanya gugatan perceraian untuk mendapatkan surat keterangan, harus dicantumkan alasan yang lengkap yang mendasarinya.

\section{AKIBAT HUKUM PERCERAIAN PEGAWAI NEGERI SIPIL}


Perceraian adalah peristiwa hukum yang akibatnya diatur oleh hukum, atau peristiwa hukum yang diberi akibat hukum lebih lanjut dari Perceraian sebagaimana diatur dalam

Pasal 41 Undang-Undang No. 1 Tahun 1974 yang berbunyi "Baik bapak atau ibu tetap berkewajiban memelihara dan mendidik anakanaknya, semata-mata berdasarkan kepentingan anak ,bilamana ada perselisihan mengenai penguasaan anak-anak,pengadilan memberi keputusannya".

\section{AKIBAT HUKUM PERCERAIAN PEGAWAI NEGERI SIPIL TANPA SEIZIN PEJABAT ATASAN LANSUNG}

Jika terdapat permohonan izin untuk bercerai yang diajukan Pegawai Negeri Sipil dengan alasanalasan yang bertentangan dengan ajaran atau Peraturan agama yang dianut Pegawai Negeri Sipil yang bersangkutan sebagaimana diberikan beberapa contohnya tersebut, maka Pejabat tidak memberikan izin untuk bercerai kepada Pegawai Negeri Sipil tersebut. Pegawai Negeri Sipil yang tidak memperoleh izin atau surat keterangan untuk bercerai lebih dahulu dari Pejabat dan tidak melaporkan Perceraiannya dalam jangka waktu selambat-lambatnya 1(satu) bulan terhitung mulai terjadinya Perceraian, dikualifikasikan melanggar hukum khusus Perceraian.

Pasal 15 ayat (1) Peraturan Pemerintah Nomor 45 Tahun 1990 yang berbunyi "jika tidak melaporkan perceraianya dalam jangka waktu selamat-lambatnya satu bulan terhitung mulaiterjadinya Perceraian dan tidak melaporkan Perkawiannya yang kedua/ketiga/kempat dalam jangka waktu selambat-lambatnya satu tahun terhitung sejak Perkawinan tersebut dilangsungkan".

\section{KESIMPULAN DAN SARAN}

\section{A. KESIMPULAN}

1. Pengaturan tentang Perkawinan dan Perceraian bagi Pegawai Negeri Sipil sudah di tentukan dalam Undang-Undang Nomor 1 Tahun 1974 tentang Perkawinan, dan Peraturan Pemerintah Nomor 45 Tahun 1990 tentang Perubahan atas Peraturan Pemerintah Nomor 10 Tahun 1983 tentang Izin Perkawinan dan Perceraian Bagi Pegawai Negeri Sipil. Dan Peraturan pelaksanaan yang terdiri dari Surat Edaran Kepala Badan Administrasi Kepegawaian Negara Nomor: 48/SE/1990, Petunjuk pelaksanaan untuk menyelesaikan masalah Perceraian Pegawai Negeri Sipil. Setiap Pegawai Negeri Sipil yang akan melakukan perceraian, yaitu bagi Pegawai Negeri Sipil (penggugat) wajib memperoleh izin terlebih dahulu dari pejabat. Permintaan izin Perceraian diajukan oleh penggugat kepada pejabat secara tertulis, tetapi Peraturan ini sangat sulit dilakukan oleh Peegawai Negeri Sipil yang akan melakukan Perceraian karena ada beberapa alasan yang tertentu. Salah satu alasannya adalah sulitnya mendapatkan Izin secara langsung dari atasan.

2. Dapat dipastikan Akibat Hukum Perceraian Pegawai Negeri Sipil yang Tidak Ada Izin Dari Atasan Langsung akan sangat sulit melakukan Perceraian. Tetapi 
jika Pegawai Negeri Sipil yang bersangkutan tidak mendapatkan izin Perceraian dari pejabat maka, majelis hakim tetap dapat mengabulkan dan dapat melanjutkan Perceraian kepada Pegawai Negeri Sipil yang bersangkutan. Dalam pemeriksaan perkara Perceraian Pegawai Negeri Sipil mejelis hakim tetap tunduk kepada Peraturan Perundang-undangan yang ada, apabila alasan-alasan yang di kemukakan oleh Pegawai Negeri Sipil yang bersangkutan terbukti maka majelis hakim dapat mengabulkan Perceraian tersebut.

\section{B. SARAN}

Adapun saran terkait penulisan hukum ini adalah sebagai berikut :

1. Diharapkan agar setiap Pegawai Negeri Sipil berfikir dan bertindak secara matang dan lebih dewasa lagi sebelum melakukan Perceraian karena pada dasarnya Pegawai Negeri Sipil adalah contoh masyarakat dan apabila Perceraian harus tetap terjadi maka Pegawai Negeri Sipil harus mau, taat, dan wajib melakukan prosedur yang berlaku untuk lebih mudah memperoleh izin dari Pejabat atasan langsung.

2. Pejabat juga harus bisa mengevaluasi kembali prosedur pemberian izin Perceraian yang berlaku selama ini dan di harapkan dapat di ketahui letak kesulitan dar prosedur pemberian izin Perceraian yang berlaku selam ini. Dan menurut saya hendaknya ada suatu kerja sama antara Pejabat Langsung pemberi izin dengan majelis hakim sehingga putusan yang diberikan dapat memberikan kepastian hukum atau rasa keadilan baik Pegawai Negeri Sipil yang bersangkutan maupun keluarga (bekas suami/istri) .

\section{DAFTAR PUSTAKA}

\section{LITERATUR}

Abdurrahman, Kompilasi Hukum Islam di Indonesia. Akademika Pressindo. Jakarta. 2010.

Djoko Prakoso. Hukum Kepegawaian di Indonesia. Balai Aksara, Yudhistira. Jakarta. 1984.

Jhonny Ibrahim, Teori dan Metode Penelitian Hukum Normatif, Banyumedia Publishing, Malang 2016

H. Hilman Hadikusuma. Hukum Perkawinan Indonesia. Mandar Maju. Bandung. 2007.

Martiman Prodjohamidjojo. Hukum Perkawinan. CV. Karya Gemilang. Jakarta Selatan. 2011.

Muhammad Syaifuddin. dkk, Hukum Perceraian. Sinar Grafika. Jakarta. 2014.

Peter Mahmud Marzuki. Penelitian Hukum. Universitas Airlangga Surabaya.

Sri Hartini dan Setiajeng Kadarsih, 2007, Hukum Kepegawaian di Indonesia, Sinar Grafika, Purwokerto

\section{PERATURAN PERUNDANG- UNDANGAN}


Undang-Undang Nomor 1 Tahun 1974 Tentang Perkawinan.

Undang-Undang Nomor 5 Tahun 2014 Tentang Aparatur Sipil Negara.

Peraturan Pemerintah Nomor 45 Tahun 1990 Tentang Perubahan atas Peraturan Pemerintah Nomor 10 Tahun 1983 Tentang Izin Perkawinan dan Peceraian Bagi Pegawai Negeri Sipil.

Peraturan Pemerintah Nomor 53 Tahun 2010 Tentang Disiplin Pegawai Negeri Sipil.

\section{INTERNET}

http://infokepegawaian.wordpress.co m.diakses tanggal 6 Juni 2017 pukul 12:30:09 WIB 